\title{
Ecological principles and stream restoration
}

B. L. Madsen, P. J. Boon, P. S. Lake, S. E. Bunn, C. N. Dahm, T. E. Langford and M. Zalewski

\section{Introduction}

The practice of stream restoration has grown rapidly over the past 20 years. In a recent editorial in the journal Aquatic Conservation, ORMEROD (2004) reported more than 300 papers in the ISI ${ }^{\circledR}$ database containing the terms 'river restoration', 'river rehabilitation', 'stream restoration' or 'stream rehabilitation' in the title, abstract or keywords. Much progress has undoubtedly been made, such as the establishment of the River Restoration Centre in the UK, the European Centre for River Restoration in Denmark, and national and international conferences specialising in stream restoration (e.g. HANSEN et al. 1998).

Yet despite these encouraging signs, much remains to be done in addressing misconceptions of running waters and their restoration. Rivers and streams are conveyors of water, but they are more than conduits. They are ecosystems with diverse animal and plant life, with fluvial and ecological processes that maintain habitats and transform matter received from the catchment and produced in the streams themselves. They shape the landscape and create the floodplain within which they fashion their stream bed in a predictable but ever-changing mosaic pattern. Nevertheless, rivers and streams are the natural ecosystems that have been changed the most by man (MALMQVIST \& RUNDLE 2002; MEYBECK 2002) and they are often managed as if they were merely conduits. Few streams in 'developed' parts of the world have evaded the 'hard engineering' approach, which has changed their inherent, natural properties. The time has surely come to move on from engineering-driven stream management into the realm of 
ecologically-driven catchment management and stream restoration (POSTEL \& RICHTER 2003).

As part of the $29^{\text {th }}$ SIL Congress in Lahti, the SIL Working Group on the Conservation and Management of Running Waters convened a workshop entitled 'Ecological principles and stream restoration'. The aim of the meeting was to review progress in this field and to consider the extent to which ecological science impinges on stream restoration. This paper briefly summarises some of our main conclusions.

\section{Stream restoration - the spatial and temporal dimensions}

The relationship between running waters and their catchments has been emphasized time and again at SIL meetings during the last three decades (e.g. HYNES 1975; LIKENS 1984; STANFORD 2005). Usually stream restoration is initiated because of an awareness of the poor condition of a stream or parts of a stream, without due consideration for the wider catchment. A restoration plan, often hastily drawn up, will then ultimately be flawed because the causes of degradation (including continuing disturbance) have not been adequately identified, let alone quantified. By understanding the relative nature, strengths and spatial extent of past and current disturbances affecting both the catchment and the stream, restoration plans can be devised that concentrate on appropriate means for curtailing the more severe impacts (BOHN \& KERSHNER 2002, RONI et al. 2002).

The restoration of habitat patches, be they riparian or instream, has been a major focus of stream restoration (RONI et al. 2002). This has often been unsuccessful, even for a short period of time (e.g. PRETTY et al. 2003), as small-scale restoration projects can be overridden by large-scale disturbances such as floods or droughts.

Habitat restoration schemes are often carried out with particular biota, such as fish, as the target. Yet with localized, site-specific habitat restoration, there can be a mismatch in spatial extent between the restoration effort and the requirements of the target organism (BOND \& 
LAKE 2003). A scheme may provide non-spawning habitat but not spawning habitat; it may provide residential habitat but not refugial habitat for use when disturbances are operating (BOND \& LAKE 2005). As WIENS (1989) pointed out, small-scale ecological phenomena operate over short time-spans, whilst large-scale phenomena operate over much longer time-spans. In most cases, large-scale projects are far more effective than site-specific projects, even though they may take a long time to achieve success. Such long durations with slow rates of restoration do not appeal to many resource managers who, driven by demands of their agency or corporation, are locked into short-term planning (LAKE 2001).

A simple but important question related to spatial-temporal extent is: 'How much is enough?' How much habitat, or environmental flow, or barrier removal is needed for effective restoration? This is a question of paramount importance, yet one that is not easy to answer. For example, when restoring the vegetation of a riparian zone, what is the appropriate width, length and vegetation density for creating an effective trap for sediment, for processing nutrients, and for supplying organic matter to the river? For some riparian functions, such as shading and mitigating temperature regimes, empirical models may be used to predict the effectiveness of restoration (e.g. RUTHERFORD et al. 2004). However, many riparian restoration areas are small and isolated, and may be ineffective in performing such functions (EWEL et al. 2001). Some environmental flows proposed for Australian rivers have been of the order of $10 \%$ of mean annual flow: are such allocations merely a token or are they ecologically effective in some way, however small?

To further the ecological restoration of streams and rivers, empirical data are needed that are embedded in restoration projects. Unfortunately, projects that are appropriately monitored are few and far between (e.g. BASH \& RYAN 2002), and need to be carefully designed to allow pre- and post-restoration monitoring relative to reference conditions or to control conditions (the unrestored state) or even to both (LAKE 2001). Because worthwhile restoration projects may be set at 
large spatial scales, post-restoration monitoring may need to be longterm yet relatively inexpensive. Monitoring also must use carefully selected, unambiguous indicators. No amount of modelling can provide clear answers to questions such as 'how much is enough?'. The challenge remains for restorers of stream ecology to convince water resource managers of the high value of long-term monitoring so that it is carried out on a range of selected restoration projects. This requires enduring partnerships between scientists, resource managers and stakeholders. Such partnerships are rare at present.

A promising tool in developing strategies for preserving and enhancing natural processes in river catchment ecosystems is the concept of 'ecohydrology'. This is an integration of hydrological and ecological processes (ZALEWSKI 2000) and differs from traditional views, where ecologists often considered hydrology as a 'disturbance', while hydrologists and river managers considered biological processes as parameters with indicative value only. The concept is based on the assumption that sustainable management depends on the restoration and maintenance of established fluvial processes, nutrient cycling, and energy flows. For this to succeed, restoration must encompass broad temporal and spatial dimensions. Temporally, restoration must take account of the past, present, and (inasmuch as they can be foreseen) future scenarios such as climate change. Spatially, they must incorporate the three dimensions of river habitats - longitudinal, lateral, and vertical - and all scales from the river basin to the microhabitat.

\section{Lessons from past restoration}

Although the benefits of restoring instream habitats and natural processes are now widely recognized (HANSEN et al. 1998), success has been limited. Some projects have failed because the scope of the ecological approach has been insufficient (KONDOLF 1998).

Restoration has often focused on mimicking habitat structure rather than on addressing catchment-wide fluvial processes that can restore 
and maintain habitats. Simply returning physical diversity to a stream does not always guarantee ecological improvement. For instance, the addition of experimental riffles to streams in the Yarra catchment in Victoria did not result in improved macroinvertebrate communities (WALSH \& BREEN 2001). Catchment-scale factors such as altered hydrology and hydraulics and the delivery of poor quality stormwater runoff (e.g. by connecting impervious surfaces and streams via stormwater pipes) can limit the recovery of stream communities in urban streams (WALSH 2004). In some rivers, where industrial development has produced severe pollution even up to the source, the capacity for natural recovery is greatly reduced. In cases such as this, or where problems of poor water quality persist, physical habitat restoration by itself will be ineffective.

A lesson learned from Denmark is that restoration objectives should be described in very specific terms, with little or no room for unrealistic expectations. A good example is the Danish 'wet meadow' programme, where a pre-drainage hydrological regime is being reinstated in reclaimed meadows to enhance denitrification. Only a very small proportion of the total cost of 70 million euros has been spent on construction; nearly $80 \%$ has been used to compensate farmers, with $20 \%$ allocated to preliminary investigations, administration, and monitoring to determine whether or not the objectives of the restoration project have been met. No wet meadow project is carried out unless prior investigations, often long-term (up to $3 \mathrm{yr}$ in the initial project phase), has demonstrated that the project is likely to remove between 200 and $500 \mathrm{~kg} \mathrm{~N}-\mathrm{NO}_{3} \mathrm{ha}^{-1}$, that no net release of phosphorus or iron to the streams will occur, and that habitats in the floodplain, and eventually in the stream, will be recreated.

A widespread Danish restoration measure is to open up streams for migrating salmonids, but successful migration depends on the character of the new channel. A complete substitution of a weir or dam with a riffle often results in rapid migration (MADSEN 1995), while successful migration through fish passages is very limited (AARESTRUP \& KOED 2003). Moreover, successful migration is not the same as successful 
recolonization: a sustainable population of salmonids depends on the availability and quality of habitats and spawning areas. The latter are often destroyed by ochre and by sand from upstream stretches, most often entering through ditches and regulated brooks in farmland. Restoration should include these reaches, preferably by raising the water level in the meadows, but this is usually prohibitively expensive. A realistic alternative is to trap the ochre load in 'ochre-ponds' or in winter-inundated meadows close to stream sources.

Too often, the problem is not necessarily the failure of a restoration project, but rather the lack of information by which to judge failure or success. A large project, the National River Restoration Science Synthesis (NRRSS), has been initiated at the National Center for Ecological Analysis and Synthesis (NCEAS) to evaluate the state of river restoration in the United States (US). A team of freshwater scientists, with a detailed knowledge of restoration practices and policies in their respective regions, is investigating what is being done, what is 'working' from an environmental and conservation perspective, and what the costs and benefits are for various types of projects (http://www.nrrss.umd.edu/). Rivers are receiving much financial support for restoration because of their economic, recreational and ecological importance. This applies both to very large projects such as the Kissimmee River Restoration Project in Florida and to small reaches of headwater streams. Great public interest is mirrored in the exponential growth of restoration projects and in articles published both in newspapers and in scientific journals.

The most common goals of restoration in US streams are riparian management, water quality management, instream habitat improvement, and bank stabilization. Few projects are analyzed in depth, however, and very few audited for ecological success. To maintain continued support, it is crucial to document whether rivers really benefit from restoration efforts. Policy makers need factual information on the effectiveness of their decisions, but evaluation is often difficult because there has been no monitoring of streams prior to restoration. An important objective of the NRRSS is to determine the 
role of ecological knowledge in river restoration. Information has been compiled from approximately 29,000 projects. The number of projects in regional databases exceeds the federal databases by a factor of almost 10; the federal projects, however, have more data on costs and are more commonly evaluated. The NRSS will identify common elements in successful ecological restoration of streams and rivers, as well as critical gaps in ecological knowledge that must be filled to facilitate more effective restoration (PALMER et al. 2005).

The project has been designed with American Rivers as a 'grassroots' partner, offering a valuable opportunity to advance the practice of restoration in the US, as well as policies related to the re-establishment of natural properties of rivers. The results will be widely disseminated and made available to policy makers and river restoration groups across the US.

In Australia many of the streams, rivers and wetlands are in a degraded state and millions of dollars are spent each year on restoration. Unfortunately, as in the US, little of the past restoration effort has been underpinned by a strong scientific base, and few attempts have been made to measure environmental benefits. An important role for the Cooperative Research Centre for Freshwater Ecology (CRCFE) has been to provide the essential ecological knowledge that is needed to support practical restoration measures (COTTINGHAM et al. 2002). The core research objective of the Restoration Ecology Program of the CRCFE is to understand the ecological processes facilitating the recovery of disturbed river and stream ecosystems.

\section{Restoring native biodiversity}

A goal in stream restoration is to safeguard or to restore native biodiversity. A general assumption of most river and riparian restoration activities is that if habitats are recreated then organisms will return and ecological condition will improve (BROOKES \& SHIELDS 1996; 
PALMER et al. 1997). This implies that recovery of degraded streams and rivers is largely constrained by the availability of suitable habitat. Experimental projects undertaken by the CRCFE have shown that instream habitat manipulation (e.g. re-instatement of wood habitat) can work as a restoration technique, provided the catchment is not too severely degraded (BOND \& LAKE 2003). However, 'residential' habitat restoration may not be sufficient for long-term persistence of populations, and recent work has shown that 'extreme event' refugia (such as deeper pools and backwaters) are important for the resilience of biota such as fish to drought (LAKE 2003).

Successful stream and river restoration, however, depends not only on the availability of habitat suitable for aquatic organisms to survive and reproduce, but also on the ability of organisms to reach the new habitat via dispersal (BUNN \& HUGHES 1997). For example, while it is realistic to expect rapid recolonization by waterfowl in the recreated wet meadows and meadow-lakes in the Danish 'wet meadow projects', it is unrealistic to expect a recovery of natural vegetation, at least in the short-term, because of insufficient dispersal of propagules and the impact of nutrient enrichment in the previously cultivated meadows (VAN DIGGELEN 2003).

Several projects within the Australian CRCFE have used powerful molecular tools to determine the mechanisms and extent of dispersal of a range of stream and river animals across a broad range of geographic and topographic settings (COOK et al. 2002; HUGHES et al. 2003; 2004). Aquatic invertebrates with a mobile adult stage (e.g. flying insects) often show widespread patterns of dispersal, at least across areas of continuous forested habitat (HUGHES et al. 2000). In contrast, many fully aquatic invertebrates, such as snails, mussels, shrimp, crayfish and even some species of fish, show marked differences in genetic structure across sub-catchments, suggesting restricted dispersal on a small spatial scale (HUGHES et al. 1996). These data suggest that many aquatic organisms will have a limited ability to recolonize disturbed areas, even after they have been restored. Dispersal ability and the presence of natural barriers (e.g. 
waterfalls) can pose a major constraint to the recovery of disturbed stream ecosystems. There are additional important implications of these population genetic studies. For example, if populations of an aquatic species are naturally highly fragmented in distribution, the barrier effect of small dams and weirs may not be as significant as previously thought. This molecular work also has raised some interesting biodiversity issues with the discovery of cryptic species (BAKER et al. 2004).

\section{Conclusions}

ORMEROD (2004) provided some telling insights into the way that ecology has (or has not) been an integral part of river and stream restoration. About $50 \%$ of the published papers he examined carried the term 'habitat', implying that the work was in some way related to the needs of organisms. Yet only 36 of the 173 papers dealing with habitats evaluated specific restoration projects using empirical biological criteria such as measurements of species diversity or composition. ORMEROD (2004) concluded, much as our SIL workshop did, that all too often restoration projects lack post-project assessment, inter-disciplinary scientific studies, and a vision that is both wider than the river reach and addresses ecological functioning as well as ecological structure.

At the conclusion of the international conference on 'River Restoration: The Physical Dimension' (held in Denmark in 1996), BOON (1998) suggested that river restoration should be considered within a five-dimensional framework: conceptual, spatial, temporal, technological, and presentational. This paper has touched briefly on the spatial and temporal dimensions. The remaining three dimensions deserve a brief comment in the conclusion to this paper. Under the heading of technology is the need to ensure that restoration projects are underpinned by sound science. In terms of presentation, education in river restoration is critically important, both to encourage a partnership approach to project design, and to demonstrate that 
ecological restoration brings with it wider economic and societal benefits as well. The concept of river restoration is not the same as river management, although the two are closely linked. Thus, as ORMEROD (2004) points out, the degree of uncertainty that stream restoration will recreate natural biological characteristics emphasises the importance of wise resource management to prevent the need for restoration in the first place.

\section{References}

AARESTRUP, K. \& KOED, A., 2003: Survival of migrating sea trout (Salmo trutta) and Atlantic salmon (Salmo salar) smolts negotiating weirs in small Danish rivers. - Ecology of Freshwater Fish 12: 169 176.

BAKER, A. M., HUGHES, J. M., DEAN, J. C. \& BUNN, S. E., 2004: Mitochondrial DNA reveals phylogenetic structuring and cryptic diversity in Australian freshwater macroinvertebrate assemblages. - Marine and Freshwater Research 55: 629 - 640.

BASH, J. S. \&. RYAN, C. M., 2002: Stream restoration and enhancement projects: Is anyone monitoring? Environmental Management 29: 677 - 885.

BOHN, B. A. \& KERSHNER, J. L., 2002: Establishing aquatic restoration priorities using a watershed approach. - Journal of Environmental Management 64: 355 - 363.

BOND, N. R. \& LAKE, P. S., 2003: Local habitat restoration in streams: Constraints on the effectiveness of restoration for stream biota. Ecological Management and Restoration 4: 193 - 198. 
BOND, N. R. \& LAKE, P. S., 2005: Ecological restoration and largescale ecological disturbances: Effects of drought on a stream habitat restoration experiment. Restoration Ecology (in press).

BOON, P. J., 1998: River restoration in five dimensions. In HANSEN, H. O., BOON, P. J, MADSEN, B. L. and IVERSEN, T. M. eds.: River restoration: The physical dimension. - Aquatic Conserv: Mar. Freshw. Ecosyst. 8: 257 - 264.

BROOKES, A. \& SHIELDS, F. D., 1996: River Channel Restoration: Guiding Principles for Sustainable Projects. John Wiley, Chichester.

BUNN, S. E. \& HUGHES, J. M., 1997: Dispersal and recruitment in streams: Evidence from genetic studies. - J. N. Am. Benthol. Soc. 16: $338-346$.

COOK, B. D., BUNN, S. E. \& HUGHES, J. M., 2002: Genetic structure and dispersal of Macrobrachium australiense (Decapoda:

Palaemonidae) in western Queensland, Australia. - Freshwater Biology 47: 2098 - 2112.

COTTINGHAM, P., BUNN, S. \& QUINN, G., 2002: Using ecological knowledge to underpin river rehabilitation. - Water 29: 33 - 36.

EWEL, K. C., CRESSA, C., KNEIB, R. T., LAKE, P. S., LEVIN, L. A., PALMER, M. A., SNELGROVE, P. \&. WALL, D. H., 2001: Managing critical transition zones. - Ecosystems. 4: 452 - 460.

HANSEN, H. O., BOON, P., MADSEN, B. L. \& IVERSEN, T. M. eds., 1998: River Restoration: The Physical Dimension. - Aquatic Conserv: Mar. Freshw. Ecosyst. 8: 1 - 264.

HUGHES, J., BAKER, A. M, BARTLETT, C., BUNN, S., GOUDKAMP, K. \& SOMERVILLE, S.,2004: Past and present patterns of connectivity 
among populations of four cryptic species of freshwater mussels Velesunio spp. in central Australia. - Molecular Ecology - 13: 3197 3212.

HUGHES, J. M., BUNN, S. E., CLEARY, C. \& HURWOOD, D. A., 2000: A hierarchical analysis of the genetic structure of an aquatic insect (Baetidae: Ephemeroptera). - Heredity 85: 561 - 570.

HUGHES, J .M., BUNN, S. E., HURWOOD, D. A., CHOY, S. \& PEARSON, R.,1996: Genetic differentiation among populations of Caridina zebra (Decapoda: Atyidae) in tropical rainforest streams, northern Australia. - Freshwater Biology 36: 289 - 296.

HUGHES, J. M., MATHER, P. B., HILLYER, M. J., CLEARY, C. \& PECKARSKY, B., 2003:. Genetic structure in a montane mayfly Baetis bicaudatus (Ephemeroptera : Baetidae), from the Rocky Mountains, Colorado. - Freshwater Biology 48: 2149 - 2162.

HYNES, H. B .N.,1975: The stream and its valley. - Verh. Internat. Verein. Limnol. 19: 1 - 15.

KONDOLF, G. M., 1998: Lessons learned from river restoration projects in California. In HANSEN, H. O., BOON, P. J., MADSEN, B. L. \& IVERSEN, T. M. eds.: River restoration: The physical dimension. Aquatic Conserv: Mar. Freshw. Ecosyst. 8: 39 - 52.

LAKE, P. S., 2001: On the maturing of restoration: Linking ecological research and restoration. - Ecological Management and Restoration 2: 110 - 115.

LAKE, P.S., 2003. Ecological effects of perturbation by drought in flowing waters. - Freshwater Biology 48: 1161 - 1172. 
LIKENS, G.E., 1984: Beyond the shoreline: A watershed-ecosystem approach. Verh. Internat. Verein. Limnol. 22:1 - 22.

MADSEN, B. L.,1995: Danish Watercourses. Ten Years with the New Watercourse Act. Danish Environmental Protection Agency, Copenhagen.

MALMQVIST, B. \& RUNDLE, S., 2002: Threats to the running water ecosystems of the world. -.Environmental Conservation 29: 134 - 153.

MEYBECK, M., 2002: Riverine quality at the Anthropocene:

propositions for global space and time analysis, illustrated by the Seine River. Aquat. Sci. 64: 376 - 393.

ORMEROD, S. J., 2004. Editorial: A golden age of river restoration science? Aquatic Conserv: Mar. Freshw. Ecosyst. 14: 543 - 549.

PALMER, M .A., AMBROSE, R. F. \& POFF, N. L.,1997:. Ecological theory and community restoration ecology. Restoration Ecology 4: 291 300.

PALMER, M. A., BERNHARDT, E. S., ALLAN, J. D., LAKE, P. S., ALEXANDER, G., BROOKS, S., CARR, J., CLAYTON, S., DAHM, C. N., FOLLSTAD SHAH, J., GALAT, D.L.,. GLOSS, S., GOODWIN, P., HART, D. D., HASSETT, B., JENKINSON, R., KONDOLF, G. M., LAVE, R., MEYER, J. L., O’DONNELL, T. K., PAGANO, L. \& SUDDUTH. E., 2005: Standards for ecologically successful river restoration. Journal of Applied Ecology (in press).

POSTEL, S. \& RICHTER, B.,2003: Rivers for Life: Managing Water for People and Nature. Island Press, Washington, D.C.

PRETTY, J.L., HARRISON, S.S.C., SHEPHERD, D. J., SMITH, C., HILDREW, A. G. \& HEY R. D.,2003. River rehabilitation and fish 
populations: assessing the benefit of in stream structures. Journal of Applied Ecology 40: 251 - 265.

RONI, P., BEECHIE, T. J., BILBY, R. E., LEONETTI, F. E., POLLOCK, M. M. \& PESS, G. R., 2002:. A review of stream restoration techniques and a hierarchical strategy for prioritizing restoration in Pacific Northwest watersheds. North American Journal of Fisheries Management 22: 1 - 20.

RUTHERFORD, J.C., MARSH, N.A., DAVIES, P.M. \& BUNN, S.E., 2004. Effects of patchy shade on stream water temperature: how quickly do small streams heat and cool? Marine and Freshwater Research 55: 737 - 748.

STANFORD, J., 2005: Floodplain biocomplexity: Dynamic controls on emergent properties of river ecosystems. Verh. Internat. Verein. Limnol. 29 :

VAN DIGGELEN, R., 2003: Can we achieve species-rich plant communities on re-created flood plains? - Proceedings of the international conference: 'Towards natural flood reduction strategies', Warsaw. http://levis.sggw.waw.pl/ecoflood/

WALSH, C. \& BREEN, P., 2001: A biological approach to assessing the potential success of habitat restoration in urban streams. Verh. Internat. Verein. Limnol. 27: 3654 - 3658.

WALSH, C., 2004: Protection of in-stream biota from urban impacts: to minimize catchment imperviousness or to improve drainage design? Marine and Freshwater Research 55: 317 - 326.

WIENS, J.A., 1989: Spatial scaling in ecology. Functional Ecology 3: 385 - 398. 
ZALEWSKI, M., 2000: Guest Editorial. Ecohydrology - the scientific background to use ecosystem properties as management tools towards sustainability of water resources. Ecological Engineering 165: 1 - 8.

\section{$\underline{\text { Authors' addresses }}$}

B. L. MADSEN, (Retired senior officer, Nature and Forest Agency). Watercastle Old School, 38 Kirkensgaardvej, DK 7620 Lemvig, Denmark. E mail: bent@laugemadsen.dk

P. J. BOON, Scottish Natural Heritage, 2 Anderson Place, Edinburgh, EH6 5NP, UK. E-mail: phil.boon@snh.gov.uk

P. S. LAKE, School of Biological Sciences and Cooperative Research Centre for Freshwater Ecology, Monash University, Victoria 3800, Australia. E-mail: Sam.Lake@sci.monash.edu.au

S. E. BUNN, Cooperative Research Centre for Freshwater Ecology, Centre for riverine Landscapes, Griffith University, Nathan, Queensland, Australia 4111. E-mail: S.Bunn@griffith.edu.au

C. N. DAHM, Department of Biology, University of New Mexico, Albuquerque, NM 87131, USA. E-mail: cdahm@sevilleta.unm.edu

T. E. LANGFORD, Centre of Environmental Sciences, University of Southampton, Building 46, Highfield, Southampton, SO17 1BJ, UK. E-mail: terry.langford@btinternet.com

M. ZALEWSKI, Department of Applied Ecology, 
University of Lodz, 12/16 Banacha Str, 90-237 Lodz, Poland. Email: mzal@biol.uni.lodz.pl 